\title{
The Manila clam population in Arcachon Bay (SW France): Can it be kept sustainable?
}

\author{
Cécile Dang a,b,*, Xavier de Montaudouin ${ }^{\mathrm{a}, \mathrm{b}}$, Mériame Gam ${ }^{\mathrm{c}}$, Christian Paroissin ${ }^{\mathrm{d}, \mathrm{e}}$, \\ Noëlle Bru ${ }^{\mathrm{d}, \mathrm{e}}$, Nathalie Caill-Milly ${ }^{\mathrm{f}}$ \\ a Université de Bordeaux, UMR 5805, Station Marine d'Arcachon, 2 rue du Pr Jolyet, Arcachon, F-33120, France \\ b CNRS, UMR 5805, Station Marine d'Arcachon, Arcachon, F-33120, France \\ ' Université Hassan II Aïn Chock, Faculté des Sciences Aïn Chock, Département de Biologie, Km 8 Route El Jadida, B.P. 5366 Maârif, 20100 Casablanca, Morocco \\ ' CNRS, UMR 5142, Laboratoire de Mathématiques appliquées, Pau, F-64013, France \\ e Université de Pau et des Pays de l'Adour, UMR 5142, Laboratoire de Mathématiques et de ses Applications, Pau, F-64013, France \\ ${ }^{\mathrm{f}}$ IFREMER, Laboratoire Ressources Halieutiques Aquitaine, Anglet, F-64600, France
}

\section{A R T I C L E I N F O}

\section{Article history:}

Received 24 October 2008

Received in revised form 21 October 2009

Accepted 13 November 2009

Available online 29 November 2009

\section{Keywords:}

Manila Clam

Ruditapes philippinarum

Growth

Mortality

Reproduction

Population Dynamic

Production

Productivity

\begin{abstract}
A B S T R A C T
The venerid clam Ruditapes philippinarum is the most prominent suspension-feeding bivalve inhabiting muddy intertidal seagrass beds in Arcachon Bay (SW France). It is exploited by fishermen, and Arcachon Bay ranks number one in France in terms of production and total biomass of this species. Previous studies revealed a decrease in the standing stock of $R$. philippinarum since 2003 and unbalanced length-frequency distributions with a lack of juveniles and of adults $>40 \mathrm{~mm}$. Consequently, the population dynamics of this bivalve were studied at four intertidal sites and one oceanic site in Arcachon Bay. As clam size structure did not allow classical dynamics computations, field monitoring was coupled with field experiments (tagging-recapture) over two years. Monitoring of condition index and gonadal maturation stages highlighted a high variability in spawning number and intensity between sites. Recruitment events in the exploited area varied spatially but with uniformly low values. Von Bertalanffy Growth Function (VBGF) parameters $\left(K, L_{\infty}\right)$ were determined using Appeldoorn and ELEFAN methods. In the exploited sites in the inner lagoon, $K$ was relatively high (mean $=0.72 \mathrm{yr}^{-1}$ ) but $L_{\infty}$ was low $($ mean $=41.1 \mathrm{~mm})$ resulting in a moderate growth performance index $\left(\Phi^{\prime}=2.99\right)$. Growth parameters were not correlated with immersion time and $L_{\infty}$ was different between sites. Comparison of mortality coefficients $(Z)$ between cage experiments and field monitoring suggested that fishing accounts for $65-75 \%$ of total adult mortality. Low recruitment, a low growth rate and a normal mortality rate led to low somatic production (4.1 and $8.7 \mathrm{~g}$ Shell-Free Dry Weight (SFDW) $\mathrm{m}^{-2} \mathrm{yr}^{-1}$ ) and an annual $P / B$ ratio from 0.44 to $0.92 \mathrm{yr}^{-1}$. Under current conditions, the possibility of a sustainable population in Arcachon Bay will strongly depend on recruitment success and fishing management.
\end{abstract}

(c) 2009 Elsevier B.V. All rights reserved.

\section{Introduction}

The Manila clam Ruditapes philippinarum, endemic in Indo-Pacific waters, is one of the most commercially exploited bivalve mollusks in the world. Its high adaptability to various coastal environments makes this clam a very suitable species for aquaculture. Introduced to different parts of the world along with Pacific oyster Crassostrea gigas seed, the Manila clam is now widely distributed along the Pacific coast of the United States, the European Atlantic coast, the Adriatic and Aegean seas and the Indo-Pacific region (Jensen et al., 2004). R. philippinarum was introduced in Europe at the beginning of the 1970s for culture purposes, initially to France (1972) and later to England, Spain and Italy (Flassch

\footnotetext{
* Corresponding author. Université de Bordeaux, UMR 5805, Station Marine d'Arcachon, 2 rue du Pr Jolyet, Arcachon, F-33120, France. Tel.: +33 5562239 36: fax: +33556549383.

E-mail address: c.dang@epoc.u-bordeaux1.fr (C. Dang).
}

and Leborgne, 1992). This species naturalized in all these countries and became a new commercially exploited resource.

In Arcachon Bay, the Manila clam was introduced in 1980 in designated growing areas as a commercially attractive species. R. philippinarum reproduced successfully in Arcachon Bay and rapidly naturalized in intertidal sea-grass beds (Zostera noltii) (Goulletquer et al., 1987). Today, Arcachon Bay ranks first in France in terms of national production and total biomass among surveyed stocks. In 2007, fishermen harvested around 1000 metric tons (Caill-Milly et al., 2008). The minimum catch size of individuals permitted by the European Union was originally $40 \mathrm{~mm}$. In 2007, the catch size was decreased to $35 \mathrm{~mm}$.

To control the fishing effort and to create a sustainable fishery, three Manila clam standing stock studies that were carried out in Arcachon Bay highlighted an estimated total stock of $8095 \mathrm{mt}$ in 2003, $7307 \mathrm{mt}$ in 2006 and $4865 \mathrm{mt}$ in 2008 (Caill-Milly et al., 2003, 2006, 2008). These studies showed that since 2003, total and exploitable 
(>35 mm) standing stocks have been decreasing. Furthermore, in these three studies, the length-size frequency distributions were characterized by a lack of juveniles and an absence of clams larger than $40 \mathrm{~mm}$. The lack of juveniles could be the consequence of a default of gonadal maturation and/or of spawning, a high larvae mortality, or a recruitment deficiency. Two hypotheses could explain the lack of clams with $>40-\mathrm{mm}$ shell length: 1) larger clams were removed by fishermen; 2) clams are not growing over $40 \mathrm{~mm}$. In 1993, a study on reproduction and growth was carried out exclusively in clam growing areas (Robert et al., 1993). The lack of knowledge on $R$. philippinarum population dynamics in Arcachon Bay was the motivation for this study.

The present study focused on the population dynamics of the Manila clam in its natural habitat, muddy intertidal flats, at Arcachon Bay. The aim of this study was to provide reliable population dynamics parameters in terms of growth, mortality and reproduction in order to implement a fishing strategy model (Bald et al., 2009). These data allowed us to calculate the production and the productivity $(P /$ $B=$ production/biomass ratio) of the clam population. One of the greatest difficulties was that clam population size structure did not permit classical dynamics analyses due to the difficulty in identifying cohorts, as already mentioned by Ramon (2003). Consequently, field monitoring was coupled with field experiments involving individual tagged clams in enclosures (tagging-recapture method).

\section{Material and methods}

\subsection{Study sites}

Arcachon Bay is a $180-\mathrm{km}^{2}$ semi-sheltered lagoon on the southwest coast of France (Fig. 1). The inner lagoon includes $110-\mathrm{km}^{2}$ of mudflats that are colonized by a vast $Z$. noltii seagrass bed. The Manila clam R. philippinarum is, in terms of biomass, the dominant species of these intertidal flats (Blanchet et al., 2004). Arcachon Bay receives freshwater inputs mainly by the Leyre River and marine water via two channels located at the southwest end of the lagoon. These fresh and oceanic water inputs as well as the slow renewal of water by tides (Plus et al., 2006) induce salinity and temperature gradients within the bay (Bouchet, 1968). Water salinity and sediment temperature of the Manila clam habitat vary from 4 to $35 \mathrm{psu}$ and from -2 to $44^{\circ} \mathrm{C}$, respectively (Dang et al., 2008). Sediment composition is mud to muddy sands. Four sites were investigated in the inner part of the bay: Ile aux Oiseaux, Andernos, Gujan and Lanton; another site, Arguin, is located in the oceanic part of Arcachon Bay in the National Reserve of Banc d'Arguin (Fig. 1).

\subsection{Environmental parameters}

Sediment grain-size, sediment organic matter and elevation above chart datum (CD) were measured at each of twenty cage locations at the end of 2006. Elevation above CD corresponds to the height (in meters) of the bottom surface. The ten first centimeters of the sediment were sampled by a $5 \mathrm{~cm}$-diameter corer and frozen until analysis. Sediment granulometry was determined using a laser-diffractometer Malvern Master Sizer. This device uses the properties of diffraction and diffusion of particles with a laser beam. Total organic matter in the sediment was obtained by calcination $\left(550{ }^{\circ} \mathrm{C}, 2 \mathrm{~h}\right)$. Water salinity was provided by Auby et al. (1999). Topographic surveys were conducted using a DGPS (Trimble 5700) with an accuracy of about $2.5 \mathrm{~cm}$ in the horizontal and $2 \mathrm{~cm}$ in the vertical. Immersion time was calculated from a tidal curve (tide height in meters vs time in hours) with a mean tidal coefficient of 63. Sediment temperature was measured with a Prosensor Thermic Tidbit probe ( period $=1 \mathrm{~h}$, precision $0.4^{\circ} \mathrm{C}$ ) at a single station per site (Arguin 2, Ile aux Oiseaux 2, Andernos 4, Gujan 3 and Lanton 3) from December 2005 to October 2007. The choice of sediment temperature instead of water temperature was motivated by a previous study

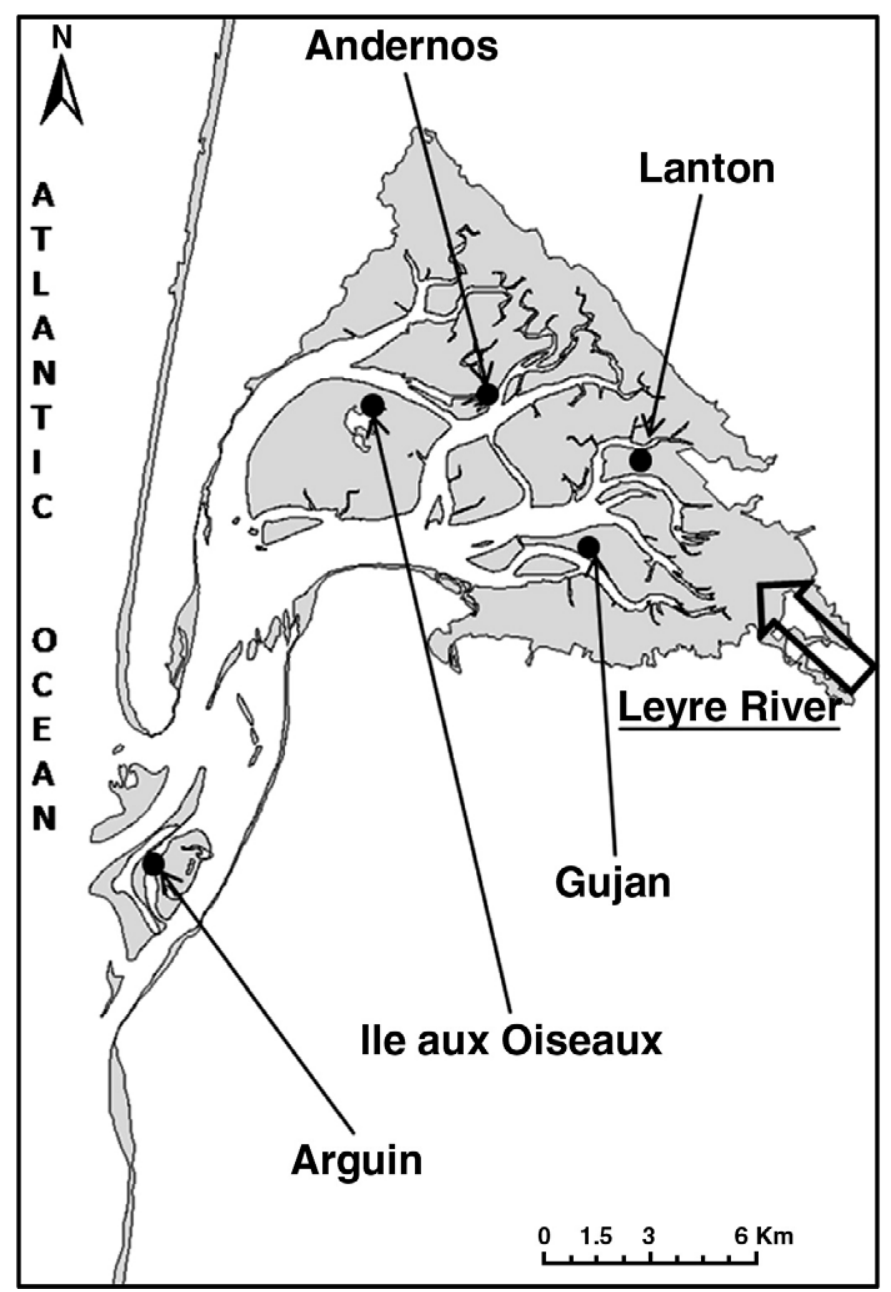

Fig. 1. Position of the five sampling sites Arguin, Andernos, Ile aux Oiseaux, Gujan and Lanton in Arcachon Bay.

comparing both temperatures between January and September 2006 $(N=5847)$. This comparison showed that the mean temperature was identical, but that sediment temperature underlined higher minimum and maximum value, that are undergone by clams and that are more realistic for these intertidal organisms. Data were collected regularly with an infrared optic shuttle and transferred to a PC with BoxCar Pro (version 3.51 for Windows) software.

\subsection{Population size structure and reproductive patterns}

Length-frequency data of the Manila clam population ambient the enclosures at Ile aux Oiseaux (November 2005 to September 2007) and at Andernos (October 2005 to September 2007) were assessed. These two sites were selected because their clam abundance is considered as 'representative' of the lagoon (Bertignac et al., 2001; Caill-Milly et al., 2003). Every other month, sampling consisted of collecting the top $15 \mathrm{~cm}$ of sediment (surface: $0.25-\mathrm{m}^{2}$ ) along a transect line $(500 \mathrm{~m})$ at each of ten stations established every $50 \mathrm{~m}$, the first station being randomly selected. The sediment was sieved through a $1-\mathrm{mm}$ mesh and $R$. philippinarum individuals were subsequently isolated in the laboratory and their shell lengths measured for assignment to size-classes from 6 to $44 \mathrm{~mm}$.

In order to assess the reproductive patterns of $R$. philippinarum in Arcachon Bay, thirty clams from 30 to $40-\mathrm{mm}$ shell length were sampled monthly over one year at Ile aux Oiseaux (December 2005February 2007) and Gujan (February 2006-February 2007); and during two years at Andernos (December 2005-October 2007) and 
Lanton (December 2005-October 2007). Clams were dissected and their condition index was evaluated separately for males and females, to assess spawning synchronicity, as $\mathrm{CI}(\%)=$ dry flesh weight $(\mathrm{mg}) /$ dry shell weight ( $g$ ) (Walne and Mann, 1975). During clam dissection, gonad development stage according to the macroscopic scale proposed by Lucas (1965) was estimated under a stereomicroscope. In stage $A$, the gonad is translucent and sex is not identifiable. In stage $\mathrm{B}$, the sex is sometimes detectible and gonads are translucent to whitish and show the early stages of maturation. Gonads of clams in stage $C$ are totally mature and strongly developed, with numerous spermatozoa and oocytes. Individuals may potentially spawn (in one or successive events) and remain in stage $C$. The gonad is whitish and inflated. When the gonad is completely empty of gametes (stage D), it becomes brown, wrinkled and flaccid. This stage can last few months. When possible, the sex ratio, i.e. number of females/number of males was determined for each date at each site.

\subsection{Growth transplant experiment}

Clams with shell-lengths between 6 and $44 \mathrm{~mm}$ were collected at Ile aux Oiseaux in November 2005. Each individual was labeled with a numbered tag and measured to the nearest $0.1 \mathrm{~mm}$ shell length before being released into different enclosures. Four enclosures were placed at each site (Arguin, Ile aux Oiseaux, Andernos, Gujan and Lanton), each one located at a different elevation from enclosure 1 (lowest level) to enclosure 4 (highest level). Each enclosure consisted of a $50 \mathrm{~cm}$ length $\times 50 \mathrm{~cm}$ width $\times 20 \mathrm{~cm}$ height topless metal frame meshed with a 2-mm plastic net, buried $15 \mathrm{~cm}$ into the sediment, projecting $5 \mathrm{~cm}$ into the overlying water column and anchored with iron bars. The sediment within the enclosure was flushed level with the surrounding sediment. We considered that enclosures just represented a barrier from which clams could be retrieved but which had little effect on local environmental conditions (grain size and grass-cover remained identical than outside the enclosure). Compared to the surrounding condition, enclosures were not considered as confounding treatments (Underwood, 1997). All enclosures were emptied of native clams before the experiment. Clam density in each enclosure was 320 ind. $\mathrm{m}^{-2}$ and the biomass was $24.2 \mathrm{~g}$ Shell-Free Dry Weight (SFDW) $\mathrm{m}^{-2}$. These represented higher values than the average in Arcachon Bay. However, such densities and biomass were locally observed (Blanchet et al., 2004; Caill-Milly et al., 2008). R. philippinarum were seasonally recaptured and their shell length was measured over a total period of two years. The obtained size increments were used for the estimation of growth parameters (see Section 2.5.1).

\subsection{Data analysis}

\subsubsection{Growth}

Von Bertalanffy growth function (VBGF) $L(t)=L_{\infty}[1-\exp [-K(t-$ $\left.t_{0}\right)$ ]] predicts length as a function of age and is commonly used in bivalve growth analysis (Bourne, 1982; Maronas et al., 2003; Fiori and Morsan, 2004; Peharda et al., 2007). This particular function was used in our work in order to allow comparisons with previous studies. $L_{\infty}$ is the asymptotic shell length ( $\mathrm{mm}), K$ is the growth coefficient $\left(\mathrm{yr}^{-1}\right)$ and $t_{0}$ is the theoretical age at zero length (yr).

In the present study, two methods were used to determine VBGF parameters i.e. $K$ and $L_{\infty}$, both using FISAT II software (version 1.2.2, FAO-ICLARM).

The first method used the measurements taken during the growth transplant experiment, i.e. length increment data obtained from each of the five stations located at Arguin, Ile aux Oiseaux, Andernos, Lanton and Gujan (total of 20 stations). $L_{\infty}$ and $K$ were assessed using Appeldoorn's method (Gayanilo et al., 2005).

The second method used the length-frequency data obtained in the 2-yr population size structure monitoring study at Andernos 4 and Ile aux Oiseaux 2. VBGF parameters were determined using the non- parametric Electronic Length-Frequency Analysis I (ELEFAN) method. This approach evaluates the best $K / L_{\infty}$ pair by assessing $R n$ coefficient (Pauly and Moreau, 1997). $R_{n}=(E S P / A S P) \times 1000$, ESP is the Explained Sum of Peaks and ASP is the Availables Sum of Peaks. A higher Rn value indicates a better fit between the components and growth curve. Limits of $K$ and $L_{\infty}$ values entered in FISAT were set at 0.4 to $1.3 \mathrm{yr}^{-1}$ and 36 to $45 \mathrm{~mm}$ respectively.

The growth performance index $\left(\Phi^{\prime}\right)$ (Pauly and Munro, 1984) was calculated using $K$ and $L_{\infty}$ using the following equation:

$\Phi^{\prime}=2 \log \left(L_{\infty}\right)+\log (K)$

\subsubsection{Mortality}

In the same way as growth parameter determination, mortality rate $Z$ was estimated using data from the growth transplant experiment and the population size structure monitoring. Mortality is the result of the decrease of abundance, generally expressed as $N_{t}=$ $N_{0} e^{-Z t}$ where $N_{0}$ is the number of individuals at relative age 0 and $t$ is the relative age, which is usually close to one year.

First, in each cage, the number of clams at experiment completion was compared to the number of clams at start. Mortality was related to shell length at the experiment's start, using tagged shell figures. Because of low number of individuals, clams were pooled by 4-mm shell length size classes to calculate a percentage of mortality throughout the duration of the experiment. Knowing shell growth (VBGF), it was consequently possible to plot a mortality curve $L n N_{t}=-Z t$ and to estimate the mortality coefficient $Z$. $N_{t}$ is the abundance (ind) at relative age $t, t$ is the time (yr) and $Z$ is the mortality constant $\left(\mathrm{yr}^{-1}\right)$. At each station, $Z$ was calculated for two intervals of clam shell lengths, 4$20 \mathrm{~mm}$ and $20-40 \mathrm{~mm}$, in order to compare results with the ELEFAN method.

Second, the instantaneous total mortality coefficient $Z$ was estimated from the 2-yr population structure monitoring at Andernos and Ile aux Oiseaux. This approach consisted of using the length-catch curve converting method (Pauly, 1983) of the FISAT II software (version 1.2.2, FAO-ICLARM) and the single negative exponential mortality model (Gayanilo et al., 2005). Lengths of pooled lengthfrequency samples were converted into ages with parameters of the VBGF. Mortality was calculated by linear regression analysis.

The curve was constructed by plotting the adjusted frequencies $(N)$ of clams in each length-class (i.e. $\log (N / \Delta t))$ against the lengthconverted mean relative age $(t)$ (Pauly and Moreau, 1997). The 2006 and 2007 years of the survey were considered together and VBGF parameters used were those calculated by Appeldoorn's method for Andernos 4 and Ile aux Oiseaux 2, which were the nearest enclosures.

\subsubsection{Biomass, production and productivity}

The annual mean biomass, the annual somatic production and the $P / B$ ratio were evaluated from the population size structure monitoring for Manila clam populations at Andernos (immersion rate: $60-70 \%$ ) and Ile aux Oiseaux (immersion rate: $45-50 \%$ ) in 2006 and 2007. Utilized VBGF parameters ( $K$ and $L_{\infty}$ ) were those obtained by the growth transplant experiment at Andernos 4 and Ile aux Oiseaux 2 (Appeldoorn's method) that were the nearest enclosures. In order to calculate production and biomass, the specific relationships between shell length, dry flesh weight and shell weight were estimated. Consequently, one hundred clams from 7 to $41 \mathrm{~mm}$ were collected at Andernos. Their dry flesh weight and shell length were evaluated to finally obtain the following equation:

$$
\log _{10} S F D W=-5.523+3.22 \log _{10} L(\mathrm{~g})\left(R^{2}=0.93\right)
$$

SFDW is the shell-free dry weight ( $\mathrm{g}$ ) and $L$ corresponds to the shell length ( $\mathrm{mm})$. 
The mean annual biomass was formulated by the following equation:

$B=\sum N_{i} M_{i}\left(\mathrm{gSFDW} \cdot \mathrm{m}^{-2}\right)$

$N_{i}$ and $M_{i}$ are the mean number of animals per $\mathrm{m}^{2}$ and the mean individual somatic mass in size class $i$.

The total annual production was calculated according to the mass specific growth rate method (Brey, 2001) from the size mass relation, the VBG equation and the pooled size-frequency distribution:

$P=\sum N_{i} M_{i} G_{i}\left(\mathrm{gSFDW} \cdot \mathrm{m}^{-2} \cdot \mathrm{yr}^{-1}\right)$

$G_{i}$ is the mass specific growth rate, which is represented by:

$G_{i}=b K\left(L_{\infty}-L_{i}\right) / L_{i}\left(\mathrm{yr}^{-1}\right)$

$b(=3.22)$ is the specific constant of the size mass relation, $K$ and $L_{\infty}$, are the VBGF parameters and $L_{i}$ is the mean size of class $i$.

The annual $P / B$ ratio of $R$. philippinarum populations were evaluated from annual total production and annual mean biomass.

\subsubsection{Statistical analysis}

To compare condition index $(\mathrm{CI})$ between months at each site, Kruskal-Wallis non-parametric test was used (Statistica software). Maximum type I error rates were set at $\alpha=0.05$. When difference was significant, a non parametric post hoc test was performed between highest and lowest values of $\mathrm{CI}$ in order to detect praks (prespawning period) from spent or rest period.

Two way Anova tests were realized to compare differences between condition index of both sexes (factors: months and sexes). When difference was significant, a post hoc test of Tukey was achieved. To evaluate a possible difference of sex ratio at each site, Chi2 test were performed.

Finally, in order to test whether the elevation above chart datum and the sites have influence over clam growth parameters ( $K$ and $L_{\infty}$ and $\Phi^{\prime}$ ), we used the non-parametric Kruskal-Wallis test with SAS software. When Kruskal-Wallis tests indicated a significant heterogeneity between treatments, a non-parametric version of the SNK test based on the sums of ranks was used to compare treatments two by two.

\section{Results}

\subsection{Environmental parameters}

The elevation above chart datum CD was determined for each station of the 5 sites (Table 1). The lowest station was at $0.8 \mathrm{~m}$ (Lanton 1) and the highest station at $2.8 \mathrm{~m}$ (Arguin 4), which corresponded to an immersion time ranging from $96 \%$ to $38 \%$ respectively (Table 1 ). Grain-size analysis discriminated Arguin (medium sand, median = $360 \mu \mathrm{m}$ ) from the four other sites (muddy sediments, median $=50$ $160 \mu \mathrm{m}$ ) located in the inner part of Arcachon Bay (Table 1). Arguin displayed the lowest values of sediment organic matter (1\%) and sediment silt (3.5\%) whereas the Lanton site inside the lagoon reached $8.5 \pm 3 \%$ and $41 \pm 12.9 \%$ respectively. Daily mean sediment temperature for the five sites was monitored (Fig. 2). Arguin differed from other sites by reduced seasonal variability, i.e. lower temperatures in summer and higher temperatures in winter (Fig. 2). Sediment minimum temperatures varied between $0.2{ }^{\circ} \mathrm{C}$ (Ile aux Oiseaux) and $-1.7{ }^{\circ} \mathrm{C}$ (Lanton), maximum temperature between $30{ }^{\circ} \mathrm{C}$ (Arguin) and $43.7^{\circ} \mathrm{C}$ (Gujan), and mean temperature between $15.1^{\circ} \mathrm{C}$ (Arguin) and $16.1^{\circ} \mathrm{C}$ (Ile aux Oiseaux) (Fig. 2). Minimum water salinity ranged between 4.8 (Lanton, Gujan) and 32.2 (Arguin), maximum salinities between 26.7 (Lanton, Gujan) and 34.2 (Arguin). Thus, Arguin was the most stable site in terms of sediment temperature and water salinity; Lanton and Gujan displayed the highest variability.

\subsection{Reproduction}

Clam reproduction was followed through condition index (CI) and gonadal maturation stages (Figs. 3 and 4). In all sites, clam CI fluctuated with lowest values in winter and highest values in spring and summer (Fig. 3). Kruskal-Wallis tests revealed significant differences of $\mathrm{CI}$ with time at the four studied sites $(P<0.005$ for the four sites). Then, post hoc tests comparisons allowed determining peaks. In 2006, clams from Andernos and Gujan exhibited the highest CI with a peak at 65\%, when Lanton and Ile aux Oiseaux reached 50\%. Peaks occurred in June and September at Andernos (Kruskal-Wallis (KW) post hoc test comparison, $P<0.05$ ) (temperature $\left(\mathrm{T}^{\circ}\right)=22.2^{\circ} \mathrm{C}$ and $21.3^{\circ} \mathrm{C}$, respectively), in May and July at Ile aux Oiseaux (KW post hoc test comparison, $P<0.05)\left(\mathrm{T}^{\circ}=18.4^{\circ} \mathrm{C}\right.$ and $25.6^{\circ} \mathrm{C}$, respectively), in June at Gujan (KW post hoc test comparison, $P<0.05)\left(\mathrm{T}^{\circ}=22^{\circ} \mathrm{C}\right)$ and in July at Lanton (KW post hoc test comparison, $P<0.05$ )

Table 1

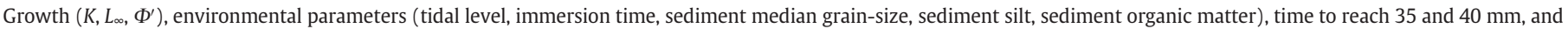
natural mortality $Z$ for clam shell length 4-20 mm $\left(Z_{1}\right)$ and $20-40 \mathrm{~mm}\left(Z_{2}\right)$ with determination coefficient $\left(R^{2}\right)$ for the 20 sampling sites in Arcachon Bay.

\begin{tabular}{|c|c|c|c|c|c|c|c|c|c|c|c|c|}
\hline Sites & $\begin{array}{l}K \\
\left(\mathrm{yr}^{-1}\right)\end{array}$ & $\begin{array}{l}L_{\infty} \\
(\mathrm{mm})\end{array}$ & $\Phi^{\prime}$ & $\begin{array}{l}\text { Tidal } \\
\text { level (m) }\end{array}$ & $\begin{array}{l}\text { Immersion } \\
\text { (\% of time) }\end{array}$ & $\begin{array}{l}\text { Sediment } \\
\text { median }(\mu \mathrm{m})\end{array}$ & $\begin{array}{l}\text { Sediment } \\
\text { silt (\%) }\end{array}$ & $\begin{array}{l}\text { Sediment organic } \\
\text { matter }(\%)\end{array}$ & $\begin{array}{l}\text { Time to reach } \\
35 \mathrm{~mm}(\mathrm{yr})\end{array}$ & $\begin{array}{l}\text { Time to reach } \\
40 \mathrm{~mm}(\mathrm{yr})\end{array}$ & $\begin{array}{l}Z_{1} \\
\left(\mathrm{yr}^{-1}\right)-\left(R^{2}\right)\end{array}$ & $\begin{array}{l}Z_{2} \\
\left(\mathrm{yr}^{-1}\right)-\left(R^{2}\right)\end{array}$ \\
\hline Arguin 1 & 0.88 & 45.89 & 3.27 & 1.57 & 75.00 & 360 & 3.5 & 1 & 1.7 & 2.4 & & \\
\hline Arguin 2 & 0.70 & 46.70 & 3.18 & 1.84 & 70.83 & 360 & 3.5 & 1 & 2 & 2.8 & $0.27(0.87)$ & $0.42(0.97)$ \\
\hline Arguin 3 & 0.55 & 46.90 & 3.08 & 2.07 & 64.58 & 360 & 3.5 & 1 & 2.5 & 3.6 & $0.40(0.90)$ & $0.22(0.94$ \\
\hline Arguin 4 & 0.39 & 43.70 & 2.87 & 2.89 & 37.50 & 360 & 3.5 & 1 & 4.2 & 6.5 & $0.66(0.88)$ & $0.11(0.97)$ \\
\hline Ile aux Oiseaux 1 & 1.04 & 38.14 & 3.18 & 1.05 & 93.75 & 118 & 33.25 & 10.02 & 2.5 & & $1.03(0.99)$ & $2.32(1.00)$ \\
\hline Ile aux Oiseaux 2 & 0.83 & 40.00 & 3.12 & 1.82 & 52.08 & 87 & 43.54 & 10.32 & 2.6 & $>10$ & $0.83(0.97)$ & $0.51(0.96)$ \\
\hline Ile aux Oiseaux 3 & 0.92 & 38.90 & 3.14 & 2.03 & 64.58 & 76 & 47.72 & 10.95 & 2.6 & & $0.61(0.96)$ & $2.66(0.95)$ \\
\hline Ile aux Oiseaux 4 & 0.68 & 38.20 & 3.00 & 2.63 & 45.14 & 97 & 42.45 & 13.05 & 3.7 & & $0.61(0.97)$ & $1.36(0.97)$ \\
\hline Andernos 1 & 0.44 & 43.70 & 2.92 & 1.18 & 87.50 & 118 & 30.70 & 9.41 & 3.7 & 5.7 & $0.79(0.69)$ & $1.11(0.99)$ \\
\hline Andernos 2 & 1.21 & 41.30 & 3.31 & 1.72 & 72.92 & 70 & 47.88 & 9.15 & 1.6 & 3 & $1.10(0.93)$ & $0.45(0.84)$ \\
\hline Andernos 3 & 0.96 & 39.50 & 3.18 & 1.83 & 68.75 & 48 & 67.96 & 10.96 & 2.3 & & $1.22(0.92)$ & $0.33(0.77)$ \\
\hline Andernos 4 & 0.97 & 39.45 & 3.18 & 2.11 & 60.42 & 163 & 14.54 & 3.33 & 2.3 & & & \\
\hline Lanton 1 & 0.45 & 43.60 & 2.93 & 0.83 & 95.83 & 95 & 40.73 & 10.17 & 3.7 & 5.7 & $0.35(0.9)$ & $0.75(0.95)$ \\
\hline Lanton 2 & 0.58 & 44.60 & 3.06 & 1.36 & 81.94 & 111 & 32.19 & 9.68 & 2.7 & 4 & $0.30(0.86$ & $0.22(0.99)$ \\
\hline Lanton 3 & 0.51 & 42.10 & 2.96 & 1.89 & 70.83 & 78 & 40.99 & 10.09 & 3.6 & 6 & $0.47(1.00)$ & $0.52(1.00)$ \\
\hline Lanton 4 & 0.49 & 43.90 & 2.98 & 1.91 & 65.97 & 94 & 36.38 & 8.49 & 3.3 & 5 & $0.23(0.91)$ & $0.35(0.93)$ \\
\hline Gujan 1 & 0.88 & 41.20 & 3.17 & 0.90 & 95.83 & 144 & 23.09 & 2.52 & 2.2 & 4.2 & $0.61(0.98)$ & $0.25(1.00)$ \\
\hline Gujan 2 & 0.52 & 42.40 & 2.97 & 1.46 & 75.00 & 69 & 47.17 & 5.63 & 3.4 & 5.7 & $0.68(0.92)$ & $0.27(0.95)$ \\
\hline Gujan 3 & 0.43 & 41.60 & 2.87 & 1.68 & 66.67 & 63 & 53.13 & 5.58 & 4.4 & 7.8 & $1.16(0.95)$ & $0.80(0.94)$ \\
\hline Gujan 4 & 0.57 & 40.10 & 2.96 & 2.21 & 56.25 & 58 & 54.48 & 6.13 & 3.7 & $>10$ & & \\
\hline
\end{tabular}




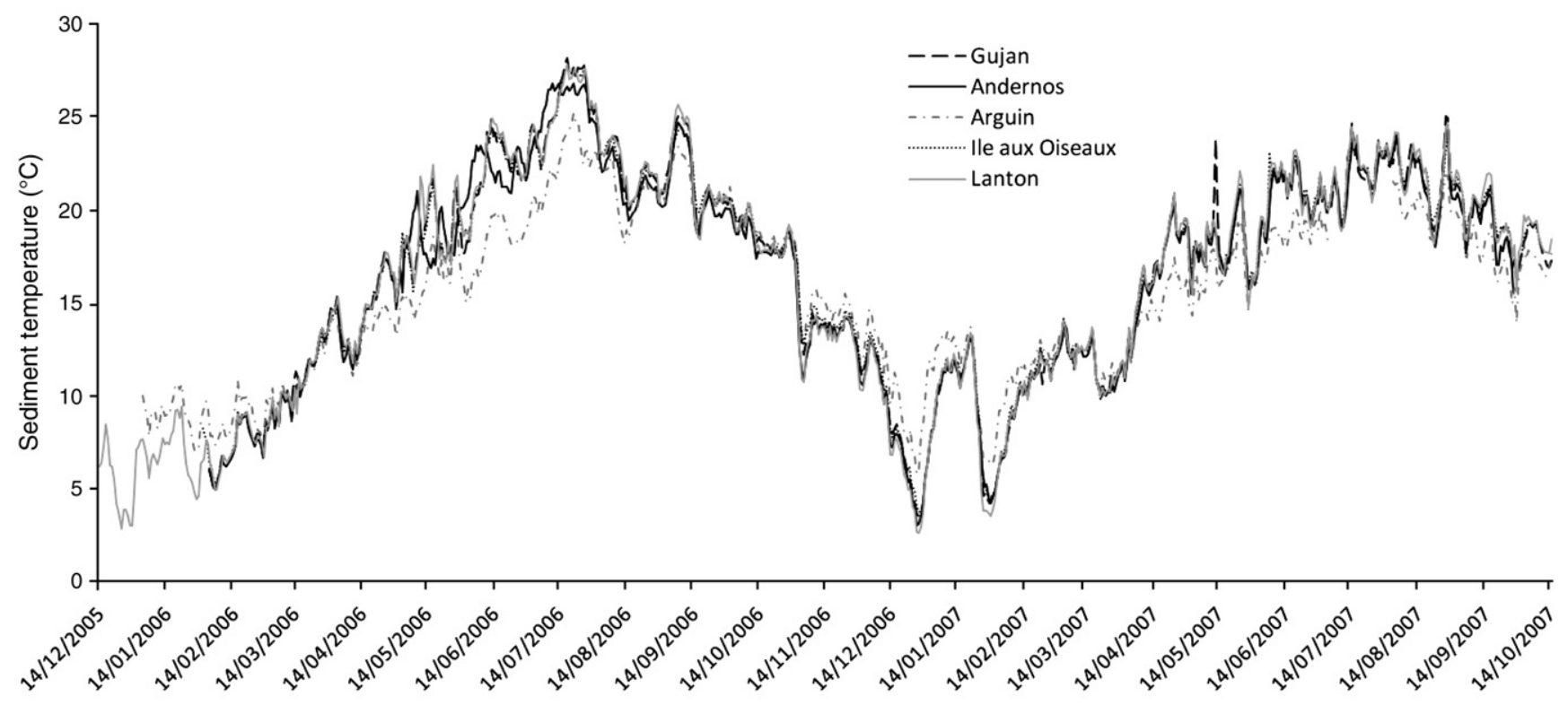

Fig. 2. Mean daily temperatures for the five studied sites from December 2005 to October 2007.

$\left(\mathrm{T}^{\circ}=25.6^{\circ} \mathrm{C}\right)$. The decrease of $\mathrm{CI}$ related to the spawning period after the gonad was ripe, i.e. reproduction stage C (Fig. 4). Gametogenesis started in March (stage B), except in the inner station of Lanton where it occurred in April (Fig. 4). It coincided with a sediment temperature of $10^{\circ} \mathrm{C}$. Spawning occurred from June to August and from September to October at Andernos; from May to June and from July to August at Ile aux Oiseaux; from June to August at Gujan; and from July to September at Lanton. In 2007, only Andernos and Lanton were monitored. At Andernos, peak CI was much lower than in 2006, when
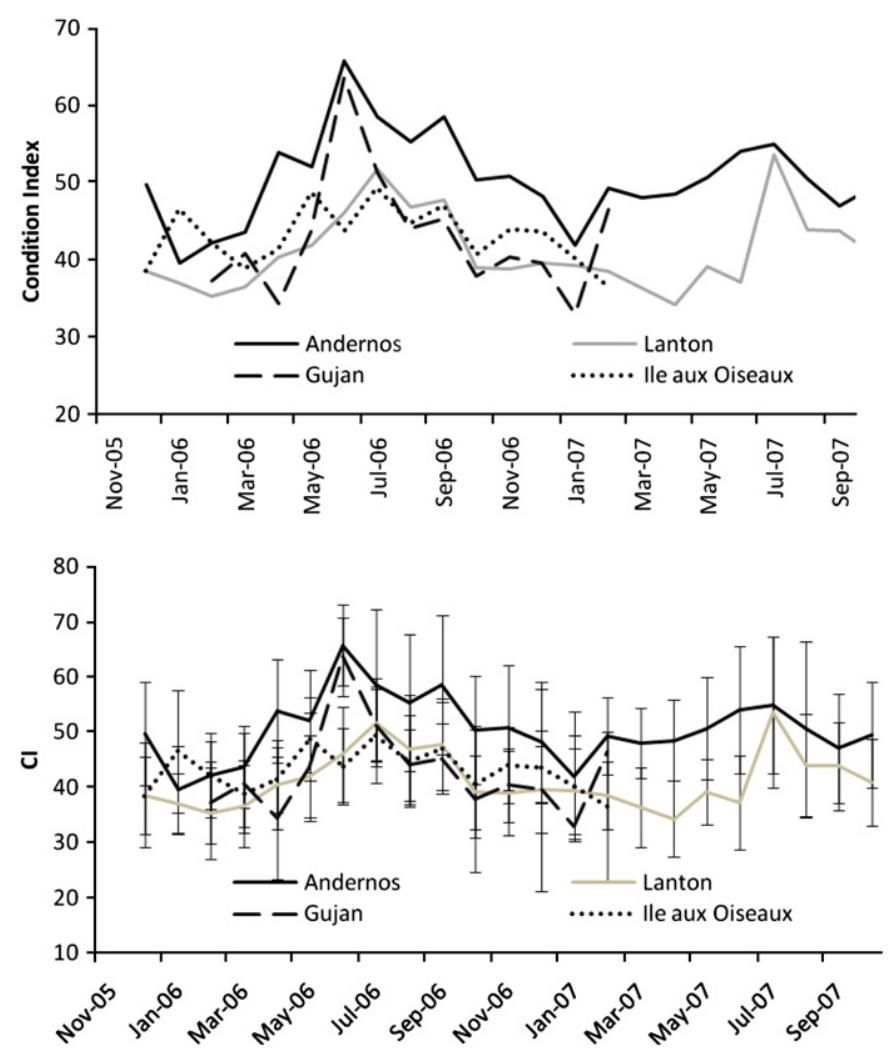

Fig. 3. Mean condition index values of Ruditapes philippinarum sampled in Andernos, Lanton, Gujan and Ile aux Oiseaux from December 2005 to October 2007. it was similar to that observed in Lanton. Maximum $\mathrm{CI}$ and spawning periods were similar in both years with a later maturation in the inner station of Lanton. As opposed to 2006, in Andernos, only one spawning occurred from July to September 2007. Temperatures were lower in 2007 , with a temperature of $21.8^{\circ} \mathrm{C}$ at Lanton in July and $21.6^{\circ} \mathrm{C}$ at Andernos in July, than in 2006 when temperatures were $25.6{ }^{\circ} \mathrm{C}$ and $25.7^{\circ} \mathrm{C}$, respectively.

$\mathrm{CI}$ did not differ between males and females (two way Anova, $P>0.05$ ) at the four studied sites but exhibited a significant different with time (two way Anova, $P<0.05$ ) at Andernos, Lanton and Gujan, at the opposite of Ile aux Oiseaux (two way Anova, $P>0.05$ ) with no significant interactions between sexes and months for all sites (two way Anova, $P>0.05$ ) (Fig. 5). Differences in CI appeared between May and June 2006 at Andernos, between June and July 2007 as well as between July and August 2007 at Lanton, between May and June 2006 and between June and July 2006 at Gujan (post hoc test of Tukey, $P<0.05$ ).

In 2006, mean sex ratios (number of females/number of males) ranged between 0.85 at Andernos ( $P>0.05), 0.93$ at Lanton $(P>0.05)$, 0.99 at Gujan $(P>0.05)$ and 1.23 at Ile aux Oiseaux $(P>0.05)$.

\subsection{Growth}

The first step consisted of calculating VBGF parameters $\left(K\right.$ and $\left.L_{\infty}\right)$ in the twenty cages through the growth transplant experiment, using Appeldoorn's method (FISAT II software) (Table 1). No significant difference was found between VBGF parameters and elevations above chart datum (CD) at each site (Kruskal-Wallis test, $P>0.05$ ). $K$ did not vary between the five sites (Kruskal-Wallis test, $P>0.05$ ). $L_{\infty}$ was significantly different among all studied sites, except between Andernos and Gujan. Growth performance index $\Phi^{\prime}$ did not differ between sites and between elevations above $C D$ at each site (Kruskal-Wallis test, $P>0.05$ ).

The second step consisted of determining VBGF parameters $K$ and $L_{\infty}$ through the length distribution data analysis with the ELEFAN I's method (FISAT II software) at Ile aux Oiseaux and Andernos. Length size frequency distributions are represented in Fig. 6. These histograms show the scarcity of juvenile $R$. philippinarum at Ile aux Oiseaux and especially at Andernos, as well as the scarcity of adults $>40 \mathrm{~mm}$, compared to the abundance of the clams of $28-40 \mathrm{~mm}$ in shell length. Few juveniles occurred in spring in March 2006 at Andernos and in April 2007 at Ile aux Oiseaux.

The best pairs $K / L_{\infty}$ obtained by ELEFAN I were $\left[1.03 \mathrm{yr}^{-1} /\right.$ $37.8 \mathrm{~mm}]$ at Andernos and $\left[0.81 \mathrm{yr}^{-1} / 37.8 \mathrm{~mm}\right]$ at Ile aux Oiseaux. 

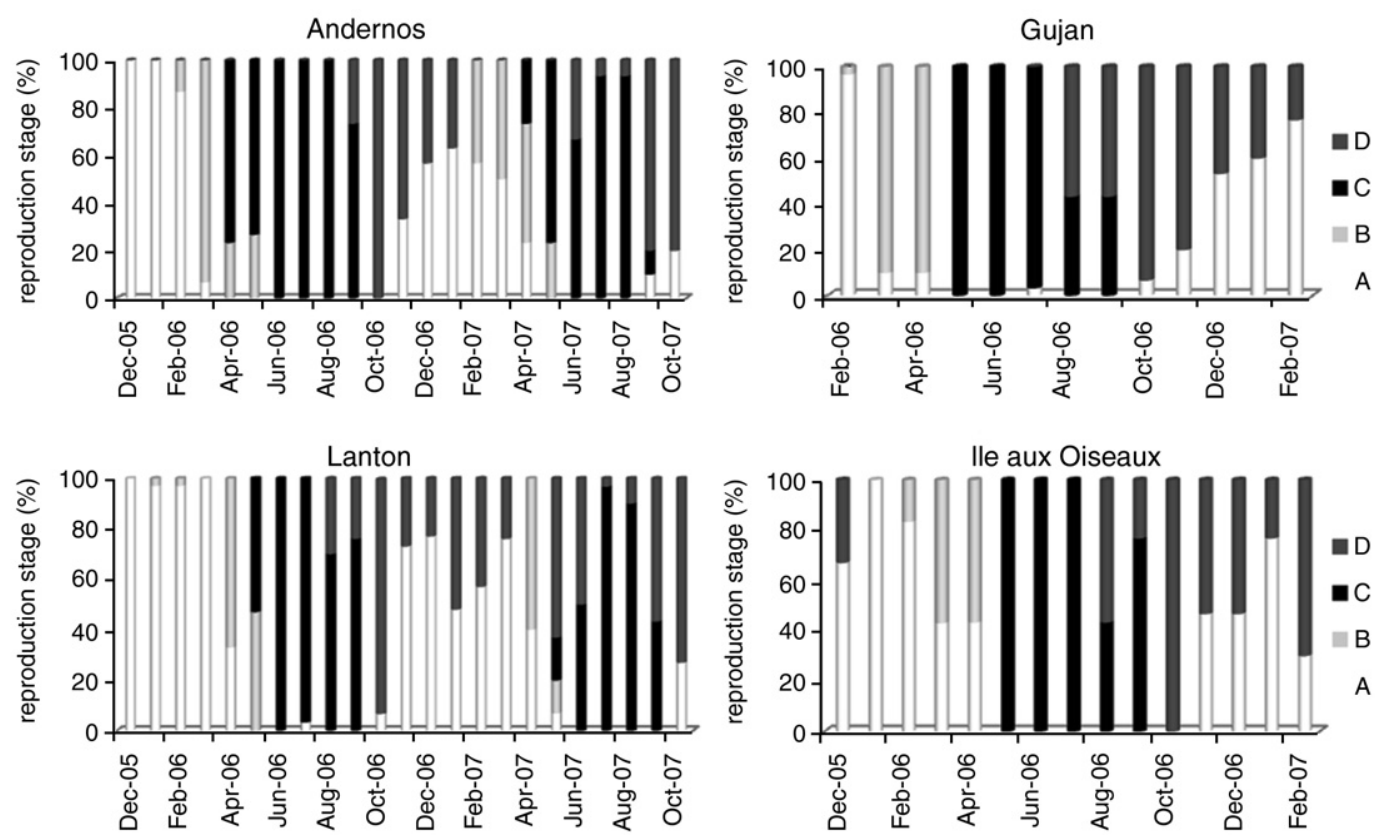

Fig. 4. Reproduction stages (A, B, C and D) of Ruditapes philippinarum from December 2005 to October 2007 in Andernos, Lanton, Ile aux Oiseaux and Gujan.

The $K$ value was similar to the one found by our growth experiment (nearest enclosures: Ile aux Oiseaux 2 and Andernos 4) at both sites whereas the asymptotic length was lower.

\subsection{Mortality}

The first method of $Z$ assessment was based on individual mortality in experiment enclosures. $Z$ mortality coefficients varied between stations and length-classes but were generally $<1.5 \mathrm{yr}^{-1}$, except on two occasions (larger length-class at Ile aux Oiseaux 1 and 3) (Table 1).

The second estimation of $Z$ was performed using the lengthconverted catch curve method (FISAT II) and the 2-yr population structure monitoring at Ile aux Oiseaux and Andernos. Size classes were determined following the size-converted catch curve and determination coefficient (Fig. 7). For both sites, the mortality rate was higher for juveniles than adults. At Andernos, mortality rate was $Z=5.83 \mathrm{yr}^{-1}\left(R^{2}=0.74\right)$ for size classes $9-19 \mathrm{~mm}$ and $Z=1.41 \mathrm{yr}^{-1}$ $\left(R^{2}=0.98\right)$ for $33-38 \mathrm{~mm}$ clams (Fig. 6). At Ile aux Oiseaux, mortality rate was $Z=3.43 \mathrm{yr}^{-1}\left(R^{2}=0.97\right)$ for size classes $8-20 \mathrm{~mm}$ and $Z=1.44 \mathrm{yr}^{-1}\left(R^{2}=0.98\right)$ for adult clams of $30-37 \mathrm{~mm}$ (Fig. 7$)$.

\subsection{Biomass, production and productivity $(P / B)$}

Mean annual clam abundance was 41.8 and 44.5 ind. $\mathrm{m}^{-2}$ at Andernos in 2006 and 2007 respectively, and for Ile aux Oiseaux it was 63.6 and 120.9 ind. $\mathrm{m}^{-2}$ in 2006 and 2007 respectively (Table 2).
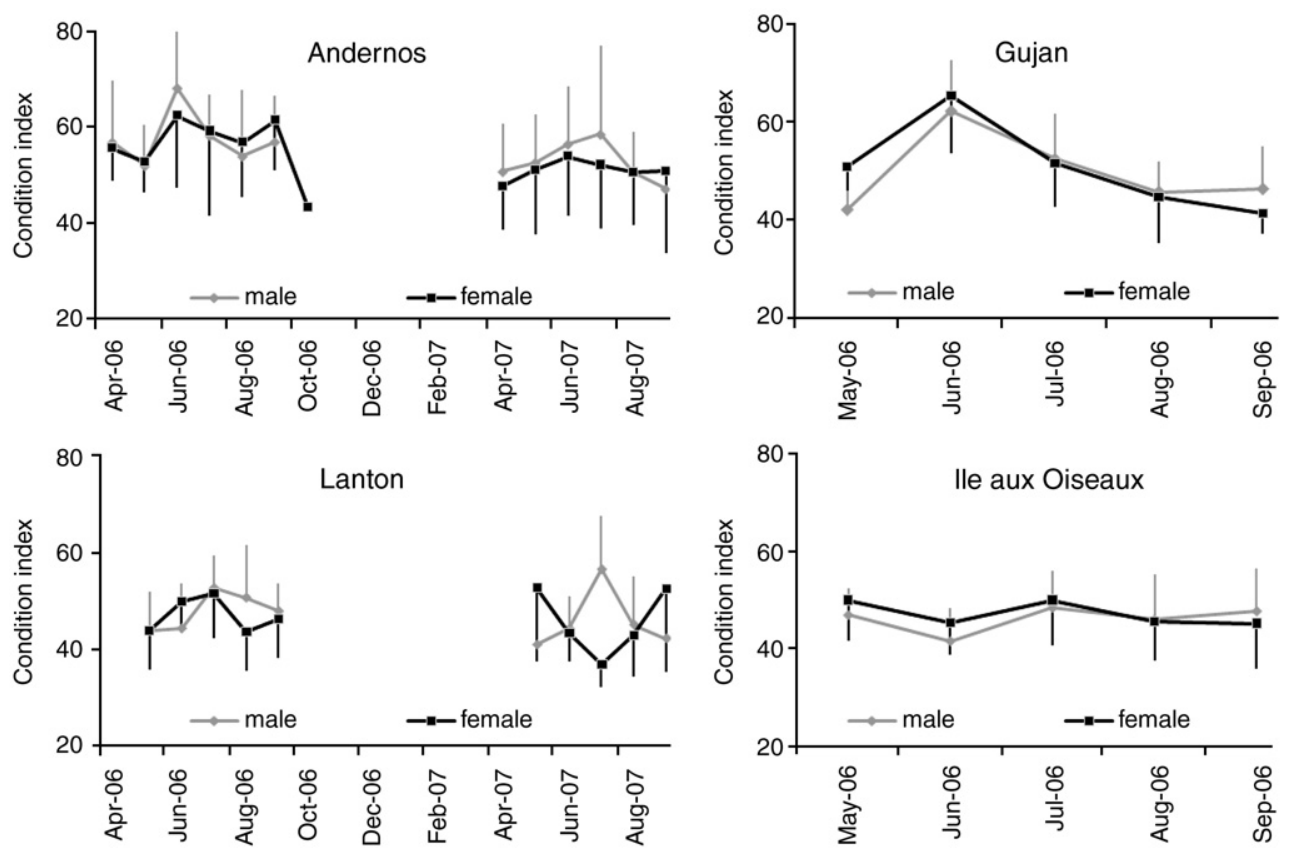

Fig. 5. Condition index $( \pm$ SD) of Ruditapes philippinarum male and female sampled in Andernos, Lanton, Gujan and Ile aux Oiseaux from December 2005 to October 2007. 

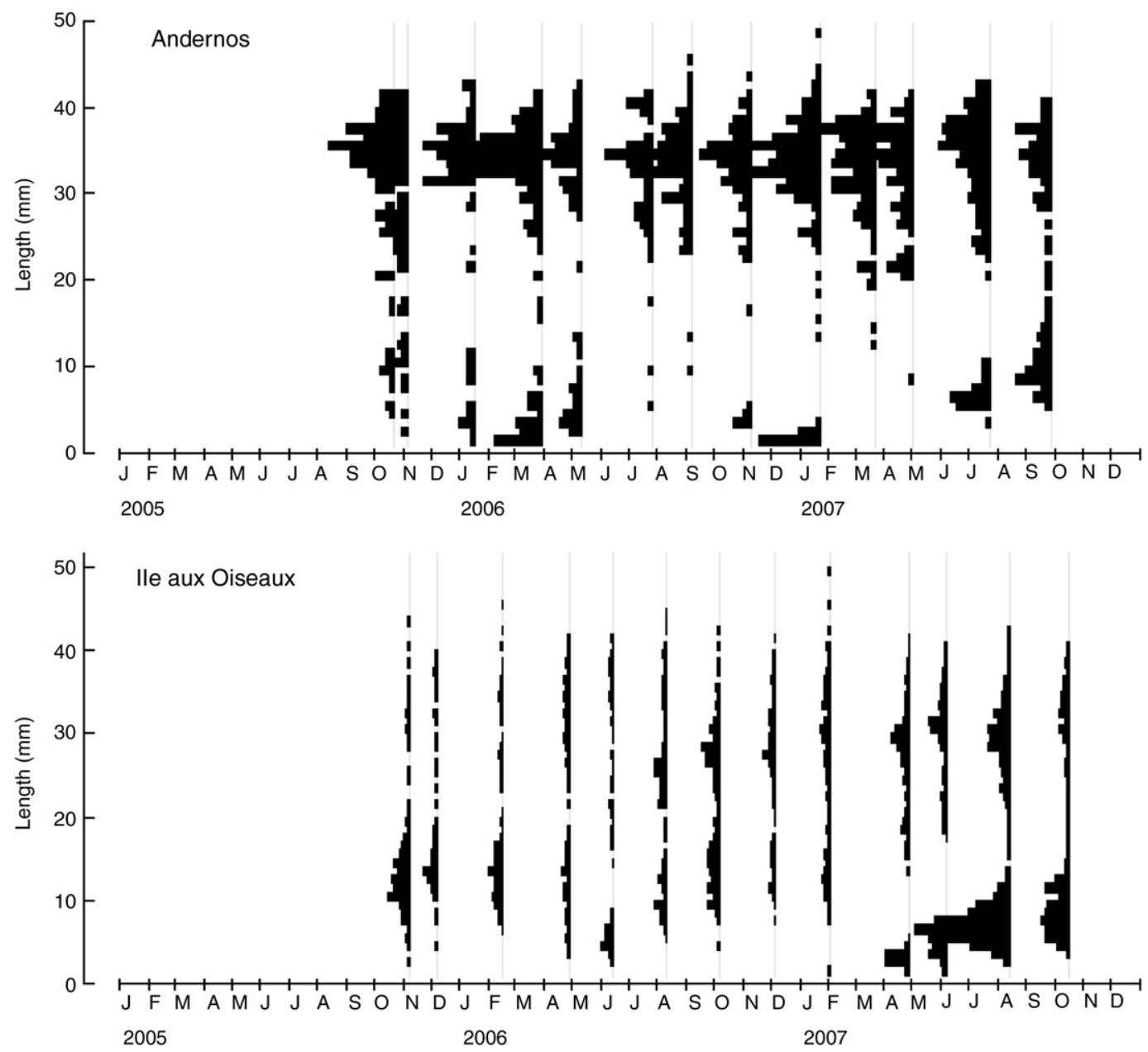

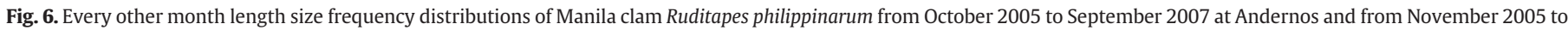
September 2007 at Ile aux Oiseaux.

Difference between both sites was due to the higher abundance of juveniles at Ile aux Oiseaux. It represented mean annual biomass estimates of $9.3 \mathrm{~g} \mathrm{SFDW} \mathrm{m}^{-2}$ (2006) and $10.1 \mathrm{~g} \mathrm{SFDW} \mathrm{m}^{-2}$ (2007) at Andernos, and $5.8 \mathrm{~g} \mathrm{SFDW} \mathrm{m}^{-2}$ (2006) and $10.5 \mathrm{~g} \mathrm{SFDW} \mathrm{m}^{-2}$ (2007) at Ile aux Oiseaux (Table 2). The observed relationship between length and dry weight was used to estimate production. The somatic annual production assessed was $4.1 \mathrm{~g} \mathrm{SFDW} \mathrm{m}^{-2} \mathrm{yr}^{-1}$ (2006) and $4.6 \mathrm{~g} \mathrm{SFDW} \mathrm{m}^{-2} \mathrm{yr}^{-1}$ (2007) at Andernos, and $5.3 \mathrm{~g} \mathrm{SFDW} \mathrm{m}^{-2} \mathrm{yr}^{-1}$ (2006) and $8.7 \mathrm{~g} \mathrm{SFDW} \mathrm{m}^{-2} \mathrm{yr}^{-1}$ (2007) at Ile aux Oiseaux (Table 2).
The distribution of total annual production $P$ among the size classes is illustrated in Fig. 8. The main part of production was supported by adult clams $>30 \mathrm{~mm}$ at Andernos (2006 and 2007) and Ile aux Oiseaux in 2007, whereas $P$ was sustained by both juveniles and adults at Ile aux Oiseaux in 2006. Production of adults was higher for Ile aux Oiseaux in 2007 compared to 2006 and with Andernos in 2006 and 2007 (Fig. 8). P/B ratios were similar for both years at Andernos, around $0.45 \mathrm{yr}^{-1}$, and was slightly higher in $2006\left(0.92 \mathrm{yr}^{-1}\right)$ than in $2007\left(0.82 \mathrm{yr}^{-1}\right)$ at Ile aux Oiseaux (Table 1$)$.
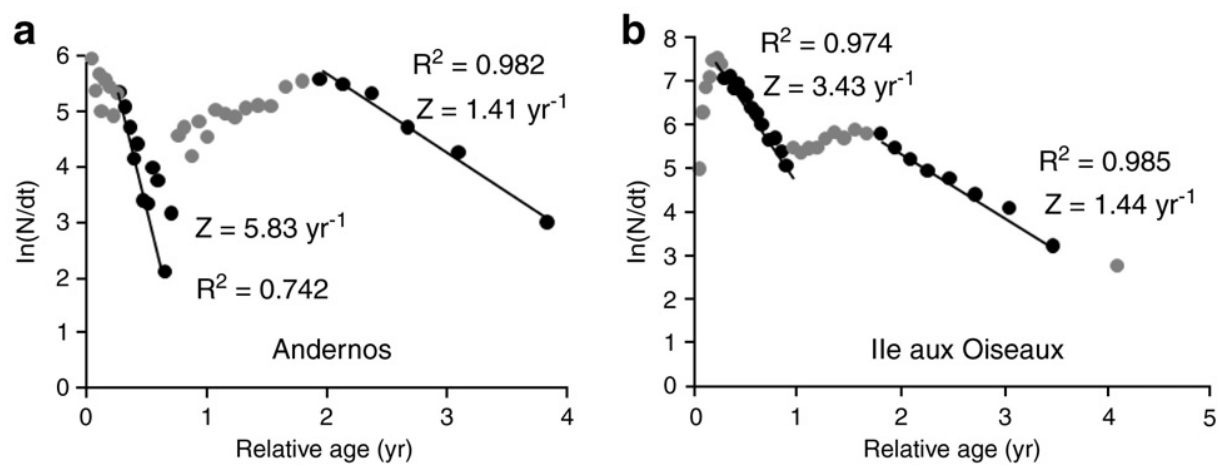

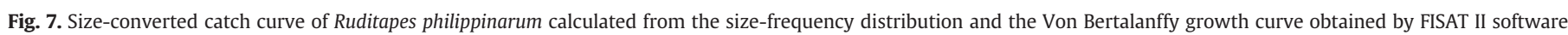
following the length catch curve converting method at Andernos and Ile aux Oiseaux. 
Table 2

Annual mean biomass, annual mean density, mean body size, somatic annual production and $P / B$ ratio calculated from the size frequency distribution, according to Brey's method, in Andernos and Ile aux Oiseaux for 2006 and 2007. B, biomass. DW, dry weight. $P$, production.

\begin{tabular}{lcllll}
\hline Site & $\begin{array}{l}B \\
\left(\mathrm{~g} \mathrm{DW} / \mathrm{m}^{2}\right)\end{array}$ & $\begin{array}{l}\text { Mean density } \\
\left(\mathrm{clam} / \mathrm{m}^{2}\right)\end{array}$ & $\begin{array}{l}\text { Mean body } \\
\text { size }(\mathrm{g} \mathrm{DW})\end{array}$ & $\begin{array}{l}\text { Somatic } P \\
\left(\mathrm{~g} \mathrm{~m}^{-2} \mathrm{yr}^{-1}\right)\end{array}$ & $\begin{array}{l}P / B \\
\left(\mathrm{yr}^{-1}\right)\end{array}$ \\
\hline $\begin{array}{l}\text { Andernos 2006 } \\
\text { Andernos 2007 }\end{array}$ & 9.30 & 41.8 & 0.22 & 4.07 & 0.44 \\
$\begin{array}{c}\text { Ile aux Oiseaux } \\
\quad 5.11\end{array}$ & 4.76 & 63.49 & 0.23 & 4.56 & 0.45 \\
$\begin{array}{l}\text { Ile aux Oiseaux } \\
\quad 10.54\end{array}$ & 120.93 & 0.09 & 5.28 & 0.92 \\
$\quad 2007$ & & 0.09 & 8.66 & 0.82 \\
\hline
\end{tabular}

\section{Discussion}

This work was realized in the context of a strong decrease in the Manila clam stock in Arcachon Bay. Recent studies showed a deficit of juveniles and a lack of large clams up to $40 \mathrm{~mm}$. The present work highlighted poor performance of the Manila clam population in terms of reproduction and growth. Indeed, gametogenesis displayed low values (analyzed through condition index evolution) and recruitment was poor (2006-7). Growth was characterized by an inability to surpass $40 \mathrm{~mm}$ shell length. Surprisingly, the $K$ parameter was similar at all sites and levels above chart datum (CD), whereas $L_{\infty}$ differed between sites (not elevation above CD) but remained in a rather low range. This situation makes the sustainability of the stock most precarious, particularly in its present exploited context.

This study confirmed the observations of previous authors on the gametogenic cycle of the Manila clam, who found a high variability following geographical location (Drummond et al., 2006). Condition index is considered as a good indicator of the spawning period (Laruelle et al., 1994; Drummond et al., 2006; Toba et al., 2007). The maximum observed $\mathrm{CI}$ corresponds to a peak in ripeness following an accumulation of resources in preparation for spawning (Drummond et al., 2006). In Arcachon Bay, spawning periods varied according to site and to year with a delay of one month between the inner station of Lanton and the three others. Clams spawned twice in 2006 and once in 2007 at Andernos, once at Lanton in 2006 and 2007, twice at Ile aux Oiseaux and once at Gujan in 2006. Consequently, this study revealed the spatial and temporal variability of spawning events at the kilometer scale within Arcachon Bay. A previous study on three sites located in Arcachon Bay showed that in 1990, a single autumn spawning period was recorded (Robert et al., 1993). Different studies around the world showed that $R$. philippinarum displays different periods of spawning by location (Table 3 ). In some cases, this period lasts for a few months as is the case in Venice lagoon (Meneghetti et al., 2004) or in the North-East Pacific (Holland and Chew, 1974; Bourne, 1982). No differences were revealed in spawning chronology between males and females, as previously reported for $R$. philippinarum from north-western France (Laruelle, 1999).

Temperature is a forcing variable for reproduction. In the present study, it was measured in the sediment because clams live in tidal flats and experience successively aerial and water influence. Manila clams have been found experimentally to begin gamete maturation when the temperature reaches $12{ }^{\circ} \mathrm{C}$, even if gametogenesis may start at $8{ }^{\circ} \mathrm{C}$ (Delgado and Pérez-Camacho, 2007). This temperature threshold was confirmed by field observations (Ohba, 1959; Holland and Chew, 1974; Mann, 1979; Xie and Burnell, 1994). In the present study, maturation began in March when mean sediment temperature was $10.5^{\circ} \mathrm{C}$ in 2006 and $11.8^{\circ} \mathrm{C}$ in 2007 . The lowest temperature limit for spawning is $14{ }^{\circ} \mathrm{C}$ (Beninger and Lucas, 1984; Rodriguez-Moscoso et al., 1992). At Arcachon Bay, gonads started to ripen in April-May, depending on the site, when sediment temperatures reached on average $14.5^{\circ} \mathrm{C}$ and $16.6^{\circ} \mathrm{C}$ in April 2006 and 2007 respectively, as well as $18.5^{\circ} \mathrm{C}$ and $18{ }^{\circ} \mathrm{C}$ in May 2006 and 2007, respectively. Most individuals were ripe during three months from May to July at Gujan and Ile aux Oiseaux and from June to August at Andernos and Lanton. Spawning events began at various sediment temperatures, i.e. $18.5^{\circ} \mathrm{C}$ at the minimum (May 2006, Ile aux Oiseaux) and $25.6^{\circ} \mathrm{C}$ at the maximum (July 2006, Lanton and Ile aux Oiseaux). Our results were in accordance with literature with a beginning of maturation at $10{ }^{\circ} \mathrm{C}$ and with spawning at a temperature
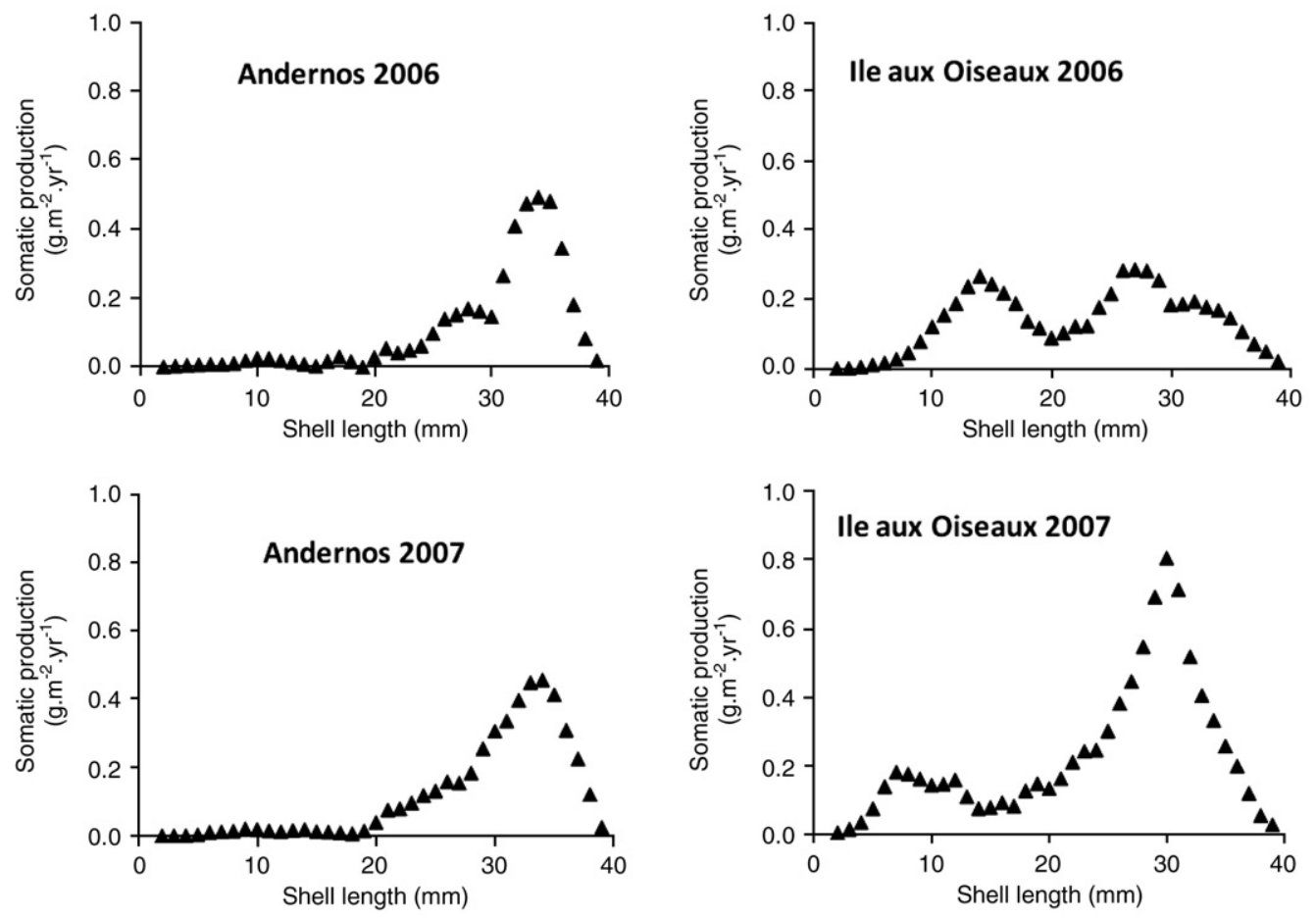

Fig. 8. Somatic annual production ( $\mathrm{g}$ SFDW. $\mathrm{m}^{-2} \cdot \mathrm{yr}^{-1}$ ) of Ruditapes philippinarum per size classes in 2006 and 2007 at Andernos and Ile aux Oiseaux. 
Table 3

Number and periods of spawning events following the geographic location.

\begin{tabular}{|c|c|c|c|c|}
\hline Country & Location & Number of spawning events & Periods & Reference \\
\hline \multirow[t]{5}{*}{ France } & Arcachon Bay & 1 & Autumn & Robert et al. (1993) \\
\hline & Ile Tudy (south Brittany) & 2 & $\begin{array}{l}\text { April to August } \\
\text { Late summer }\end{array}$ & Beninger and Lucas (1984) \\
\hline & Morbihan Gulf & 3 & $\begin{array}{l}\text { June } \\
\text { July } \\
\text { September }\end{array}$ & Laruelle et al. (1994) \\
\hline & Bay of Brest & 3 & $\begin{array}{l}\text { May } \\
\text { June } \\
\text { September }\end{array}$ & Laruelle et al. (1994) \\
\hline & Thau Lagoon & 1 & April to September & Maitre-Allain (1985) \\
\hline Spain & Ria de Vigo & 2 & June to November & Rodriguez-Moscoso et al. (1992) \\
\hline Italy & Lagoon of Venice & 1 & May to September & Meneghetti et al. (2004) \\
\hline \multirow[t]{5}{*}{ Japan } & Musaka shoal & 2 & $\begin{array}{l}\text { Late spring } \\
\text { Early to late fall }\end{array}$ & Ohba (1959) \\
\hline & Tokyo Bay & 2 & Spring to early summer & Ishii et al. (2001) \\
\hline & Ariake Sound & & Fall to early winter & \\
\hline & Tokyo Bay (Sanbanse and Kisarazu) & 2 & $\begin{array}{l}\text { Summer } \\
\text { Autumn }\end{array}$ & Toba et al. (2007) \\
\hline & Matsukawa-ura, (north Japan) & 2 & $\begin{array}{l}\text { Late June to early August } \\
\text { Late September to early October }\end{array}$ & Kanazawa and Sato (2007) \\
\hline Russia & Vostok Bay & 1 & Summer & Ponurovsky and Yakovlev (1992) \\
\hline Canada & British Columbia & 1 & June to autumn & Holland and Chew (1974), Bourne (1982) \\
\hline USA & Hood Canal, Washington & 1 & Early June to September & Nosho and Chew (1972) \\
\hline
\end{tabular}

above $14^{\circ} \mathrm{C}$. Even if it was an important factor in the determination of maturation and spawning periods, the variability of temperature during spawning in Arcachon Bay suggests that other environmental factors must be essential such as trophic sources (Laruelle et al., 1994) or salinity (proximity of the river) (Robert et al., 1993).

Clams size structure was unbalanced in Arcachon Bay as shown by histograms at Andernos and Ile aux Oiseaux as well as by previous campaigns that evaluated the standing stock in 2003, 2006 and 2008 (Caill-Milly et al., 2003, 2006, 2008). Size structure of the Manila clam was characterized by an absence of adults $>40 \mathrm{~mm}$ and by a deficit of juveniles, which was particularly alarming for the survival of the population and for the exploitation by fishermen. However, clams develop gametes at a clam shell length of 5-10 mm and reach maturity at $15-20 \mathrm{~mm}$ with all individuals over $20 \mathrm{~mm}$ able to spawn (Holland and Chew, 1974).

The lack of juveniles could be explained by three hypotheses: 1) Reproduction was not efficient enough to produce larvae. The amplitude of variation of the $\mathrm{CI}$ from reproductive to resting periods is representative of the spawning intensity. In the Laruelle et al. (1994) study, the CI was around $60 \%$ out of gametogenesis period, whereas maximum values reached $131 \%$ in the Bay of Brest and $142 \%$ in the Morbihan Gulf, against 66\% in Arcachon Bay (and around 40\% for the resting period). Consequently, the amplitude of CI variation was considerably higher in the two Brittany sites than in Arcachon Bay. Values observed in Morbihan Gulf were close to those observed in clams from Arguin, i.e. located in oceanic conditions (Dang, unpublished data). The small average length of adult clams in Arcachon Bay can also exacerbate larval depletion. 2) Larvae were produced but endured high planktonic mortality, due to unfavorable environmental conditions. Manila clam eggs require 1-2 days at a temperature of 13$16{ }^{\circ} \mathrm{C}$ to hatch, followed by an optimal temperature of $25^{\circ} \mathrm{C}$ and salinity of 20-30 for larval survival (Robinson and Breese, 1984). For instance, insufficient temperatures were the reason for the nonrecruitment of Manila clams in Southern Ireland (Xie and Burnell, 1994). 3) Reproduction occurred, larvae survived but new recruits underwent mortality due to adverse environmental conditions (low temperatures in winter) and/or predation. The density of $2-3 \mathrm{~mm}$ shell length clams in the present study was under 23 ind. $\mathrm{m}^{-2}$ in April 2007 at Ile aux Oiseaux 2 and 4 ind. $\mathrm{m}^{-2}$ in March 2006 at Andernos 4. These values are catastrophic for population survival, when related to Ohba (1959) values of $2000-2500$ ind. $\mathrm{m}^{-2}$ for a length of $2-3 \mathrm{~mm}$ and to Humphreys et al. (2007), who found settlement densities were two orders of magnitude below those of Ohba (1959). Poor survival of recruits can be the consequence of many factors, including predation (Sanchez-Salazar et al., 1987; McArthur, 1998; Hiddink et al., 2002). The density of crabs in these seagrass beds can reach 23 ind. $\mathrm{m}^{-2}$ (Blanchet et al., 2004). The role of grazing by Brent Geese remains unknown. Secondary settlement and juvenile migrations are unlikely (de Montaudouin, 1997). Only two sites were sampled in this study but previous large-scale sampling campaigns collecting all size classes of clams $>5 \mathrm{~mm}$ found small amounts of juveniles (Caill-Milly et al., 2003, 2006, 2008). In addition, a 2002 survey involving 49 stations sieved with 1-mm mesh revealed a lack of juvenile clams (Blanchet et al., 2004). Our study does not favor one of these hypotheses. However, the third hypothesis is unlikely since the juvenile mortality obtained in our study was low $\left(Z=4.6 \mathrm{yr}^{-1}\right)$.

Clam density ( 320 ind. $\mathrm{m}^{-2}$ ) and biomass $\left(24.2 \mathrm{~g} \mathrm{SFDW}^{-2}\right.$ ) in our cage experiment were about twice as high as in the field, at Ile aux Oiseaux and Andernos. However, they probably had little influence on Manila clam growth, as the cage densities were still lower than those found in many natural populations elsewhere. Also, a previous growth experiment at different clam densities failed to demonstrate an effect of clam abundance on growth between biomass ranging from 6.7 to $60.1 \mathrm{~g} \mathrm{SFDW} . \mathrm{m}^{-2}$ (Dang, unpublished data). In Tokyo Bay, before the decline of clams at the end of the 1990s, population density was consistently above 400 ind. $\mathrm{m}^{-2}$ (Toba, 2004). Ponurovskii and Selin (1988) reported a population density from 490 to 896 ind. $\mathrm{m}^{-2}$ in Vostok Bay and Breber (2002) found 384 ind. $\mathrm{m}^{-2}$ of $R$. philippinarum in Goro lagoon. Unpublished data from the Morbihan Gulf showed adult ( $>26 \mathrm{~mm}$ ) densities between 40 and 69 ind. $\mathrm{m}^{-2}$ whereas it was 
between 28 ind. $\mathrm{m}^{-2}$ (Ile aux Oiseaux) and 33 ind. $\mathrm{m}^{-2}$ (Andernos) in Arcachon Bay. Consequently, abundance of juvenile and adult clams in Arcachon Bay was lower than that of Manila clam populations in many other investigated sites.

To explain the lack of adults $>40 \mathrm{~mm}$, two hypotheses have been envisaged: large clams were collected by fishermen or clams were not able to exceed 40 -mm shell-length. Given that asymptotic length was not larger than $44 \mathrm{~mm}$ inside the bay and also that fishermen exploit all large size classes, both hypotheses are acceptable. One solution to maintain clam populations would have been that Manila clams in Arcachon Bay compensated for low recruitment by fast growth and low mortality. The necessary time to reach $40-\mathrm{mm}$ shell length depended on the site (Table 1). For instance, clams situated inside the bay required between three and sometimes more than ten yrs to reach 40-mm shell length. At Ile aux Oiseaux (cages 1, 3, 4) and Andernos (cages 3, 4), 40-mm shell length could not be attained. When considering the catch size tolerated in Arcachon Bay, i.e. $35 \mathrm{~mm}$, clams from every site can reach this length. The minimum time was 1.6 yrs at Andernos 2 and 1.7 yrs at Arguin 1 whereas it took 4.4 yrs at Gujan 3 (Table 1). The mean age to reach $35 \mathrm{~mm}$ was $2.9 \mathrm{yrs}$, with a minimum of 1.6 yrs at Andernos 2 and 4.4 yrs at Gujan 3. The growth performance index $\Phi^{\prime}$ varied neither between sites nor between elevations above CD. $K$ values in Arcachon Bay (0.3-1.21 $\mathrm{yr}^{-1}$ ) were relatively high compared to other sites such as British Columbia where they varied between 0.14 and $0.39 \mathrm{yr}^{-1}$ (Bourne, 1982). It can be partly interpreted by $L_{\infty}$ that was dramatically low $(<45 \mathrm{~mm}$ in inner lagoon) compared to what was observed in Canada (47.6-84.5 mm) (Bourne, 1982). However, low values of $L_{\infty}$ in Arcachon Bay were not unique and are found in native areas such as in Japanese waters (34.9 mm) (Ohba, 1959).

The present study showed that growth efficiency ( $K$ and $L_{\infty}$ ) was surprisingly independent of the elevation above $\mathrm{CD}$ and that $L_{\infty}$ alone was different between sites. Influence of elevation above $C D$ on growth has been demonstrated in many suspension feeders like cockles Cerastoderma edule in Arcachon Bay (de Montaudouin, 1996). A higher immersion time corresponds to a higher suspension feeding time (de Kergariou et al., 1981; Goulletquer et al., 1987) and consequently should induce high growth performances. However, Nakamura et al. (2002) and Masu et al. (2008) reported no difference in Manila clam shell length in Tokyo Bay between intertidal and subtidal stations. Bacher and Goulletquer (1989) reported that in intertidal areas, immersion time was an important factor in growth control, but even if this parameter interacted with growth performances, it was not the principal factor explaining the observed differences between sites. Similar observations have been made in a study by Masu et al. (2008) on Manila clam juveniles: shell growth was not exclusively determined by emersion and immersion but perhaps by metabolic rhythm as a result of collective effects of various environmental factors associated with tidal movements, as well as with shell valve movements. Clam growth is also influenced by food supply and water temperature (Thompson, 1984). In Tokyo Bay, Chew (1989) postulated that the growth of Manila clam was affected by temperature, salinity, exposure regime and food availability whereas Nakamura et al. (2002) showed that it could only be explained by food availability. Periods of high growth in R. philippinarum were associated with high temperatures, high chlorophyll, lipids and proteins concentrations in water column whereas periods of low growth were related to low temperatures, high turbidity and a high detritic food content in the water (Bacher and Goulletquer, 1989). Differences in asymptotic length between sites may be explained by a varied quality and quantity of trophic sources. The highest $L_{\infty}$ of this study was found at Arguin. Oceanic sites are commonly characterized by better growth performances because of higher stability of environmental parameters (salinity, temperature) (Mann, 1979; Bacher and Goulletquer, 1989; Robert et al., 1993) and higher trophic supply (Bacher and Goulletquer, 1989; Robert et al., 1993).
The mortality coefficient $Z$ was assessed in cages and in situ for two length-classes, $<20 \mathrm{~mm}$ (juveniles) and $>20 \mathrm{~mm}$ (adults). In cages, average $Z$ was $0.67 \mathrm{yr}^{-1}$ ( $=50 \%$ mortality in $12 \mathrm{mo}$ ) for juveniles. In both monitored sites (Andernos and Ile aux Oiseaux), juvenile mortality ( $Z$ ) was 4-5 times higher than in cages located in the same site. This difference may result in lower predation in cages and in the fact that juveniles in cages were larger $(>6 \mathrm{~mm})$ at the experiment start than individuals sampled with a $1-\mathrm{mm}$ mesh size (monitoring). Two cages displayed particularly high mortalities for adult clams, due to predation by the oyster drill Ocenebra erinacea $\left(Z=2.3-2.6 \mathrm{yr}^{-1}\right)$ as observed in indications from empty shells. In other cages, average $Z$ was $0.51 \mathrm{yr}^{-1}$ ( $=50 \%$ mortality in $16 \mathrm{mo}$ ). In both monitored sites, (Andernos 4 and Ile aux Oiseaux 2), adult mortality (Z) was 3-4 times higher in situ than in cages. This difference could result in fishing activity around the cages.

The stock of $R$. philippinarum in Arcachon Bay considerably decreased from 2003 to 2008 and this study highlights the alarming situation of Manila clam populations in Arcachon Bay, as a result of a poor recruitment, slow growth and high fishing effort. The annual production was $<9 \mathrm{~g}$ SFDW m ${ }^{-2} \mathrm{yr}^{-1}$ compared to $17 \mathrm{~g}$ SFDW m$^{-2} \mathrm{yr}^{-1}$ in British waters (Humphreys et al., 2007). Furthermore, the productivity in Arcachon Bay was low with a population renewal of around $0.44 \mathrm{yr}^{-1}$ and $0.87 \mathrm{yr}^{-1}$ (average of $P / B$ in 2006 and 2007) at Andernos and Ile aux Oiseaux, respectively. These values were comparable to those of cockles Cerastoderma edule from the Wadden Sea which were comprised between $0.46 \mathrm{yr}^{-1}$ and $0.66 \mathrm{yr}^{-1}$ (Ramon, 2003). They were also in the range of the venerid bivalve Callista chione with $0.45 \mathrm{yr}^{-1}$ (Metaxatos, 2004). A low $P / B$ indicates a low capacity to survive to overexploitation because $P / B$ is considered as an indicator of the maximum limit of sustainable exploitation of stock (Metaxatos, 2004).

In recent years in Japan, at Tokyo Bay and Ariake Bay, the adult stock of Manila clam has drastically decreased, coincident with poor juvenile recruitment (Ishii et al., 2001; Toba, 2004). R. philippinarum recruitment occurred twice a year in Tokyo Bay and the decline of the adult stock was associated with the unstable recruitment of summer cohorts, which was the major component of recruitment in the past (Toba et al., 2007).

The possibility of a sustainable population of the Manila clam within Arcachon Bay with such low growth and recruitment is doubtful. Consequently, the survival of Manila clam populations with current levels of extensive fishing activity is unlikely unless high and successful recruitment events occur.

\section{Acknowledgements}

C. Dang was financed by Fonds Communs Aquitaine-Euskadi and Conseil Général de la Gironde. Many thanks to F. Prince, P. Lebleu, M. Basterextea for their valuable help in clams collecting and to S. Bujan for assisting us in topographic measures. Authors are very grateful to R. B. Carnegie for English reviewing. The study was partly financed by the project Multistress (Coordinator: X. de Montaudouin) of the National Research Agency (ANR). We are grateful to SEPANSO for allowing us to work at the National Reserve of Banc d'Arguin.

\section{References}

Auby, I., Trut, G., d'Amico, F., Beliaeff, B., 1999. Réseau hydrologique du Bassin d'Arcachon - Synthèse des résultats 1988-1997. Ifremer, Paris, pp. 1-60.

Bacher, C., Goulletquer, P., 1989. Comparaison des relations trophiques de Ruditapes philippinarum en milieux estuarien et océanique à partir d'un modèle de croissance. Can. J. Fish. Aquat. Sci. 46, 1160-1170.

Bald, J., Sinquin, A., Borja, A., Caill-Milly, N Duclerq, B., Dang C De Montaudouin, X. 2009. A system dynamics model for the management of the Manila clam, Ruditapes philippinarum (Adams \& Reeve, 1850) in the Bay of Arcachon(France \& Peters). Ecol. Model. 220, 2828-2837.

Beninger, P.G., Lucas, A., 1984. Seasonal variation in condition index, reproductive activity, and growth biochemical composition of two species of adult clam reared in a common habitat: Tapes decussatus and Tapes philippinarum. J. Exp. Mar. Biol. Ecol. 79, 19-37. 
Bertignac, M., Auby, I., Foucard, J., Martin, S., de Montaudouin, X., Sauriau, P.-G., 2001 Evaluation du stock de palourdes du bassin d'Arcachon. Ifremer, pp. 1-35.

Blanchet, H., de Montaudouin, X., Lucas, A., Chardy, P., 2004. Heterogeneity of macrozoobenthic assemblages within a Zostera noltii seagrass bed: diversity, abundance, biomass and structuring factors. Estuar. Coast. Shelf Sci. 61, 111-123.

Bouchet, J.M., 1968. Etude océanographique des chenaux du bassin d'Arcachon. PhD thesis. University of Bordeaux 1. p. 306.

Bourne, N., 1982. Distribution, reproduction, and growth of Manila clam, Tapes philippinarum, in British Columbia. J. Shellfish Res. 2, 47-54.

Breber, P., 2002. Introduction and acclimatisation of the Pacific carpet clam Tapes philippinarum, to Italian waters. In: Leppäkoski, E., Gollash, S., Olenin, S. (Eds.), Invasive Aquatic Species of Europe. Distribution, Impacts, and Management. Kluwer Academic Publishers, Dordrecht / Boston / London, pp. 120-126.

Brey, T., 2001. Population dynamics in benthic invertebrates. A virtual handbook. In: Available: http://www.thomas-brey.de/science/virtualhandbook/navlog/index.html.

Caill-Milly, N., de Casamajor, M.-N., Lissardy, M., Sanchez, F., Morandeau, G., 2003. Evaluation du stock de palourdes du bassin d'Arcachon - Campagne 2003. IFREMER, pp. 1-44.

Caill-Milly, N., Duclercq, B., Morandeau, G., 2006. Campagne d'évaluation du stock de palourdes du bassin d'Arcachon. IFREMER, pp. 1-51.

Caill-Milly, N., Bobinet, J., Lissardy, M., Morandeau, G., Sanchez, F., 2008. Campagne d'évaluation du stock de palourdes du bassin d'Arcachon. Année 2008. IFREMER, pp. 1-67.

Chew, K.K., 1989. Manila clam biology and fishery development in Western North America. In: Manzi, J.J., Castagna, M. (Eds.), Clam Mariculture in North America. Elsevier, Amsterdam, pp. 243-261.

Dang, C., de Montaudouin, X., Gonzalez, P., Mesmer-Dudons, N., Caill-Milly, N., 2008. Brown muscle disease (BMD), an emergent pathology affecting Manila clam Ruditapes philippinarum in Arcachon Bay (SW France). Dis. Aquat. Org. 80, 219-228.

de Kergariou, G., Latrouite, D., Perodou, D., Claude, S., 1981. Données sur la biologie de Ruditapes philippinarum et Ruditapes decussatus en élevage sur la côte morbihannaise. In: C. d. M. e. Crustacés, editors. International Council for the Exploitation of the Sea. p. 12.

de Montaudouin, X., 1996. Factors involved in growth plasticity of cockles Cerastoderma edule (L.), identified by field survey and transplant experiments. J. Sea Res. 36, 251-265.

de Montaudouin, X., 1997. Potential of bivalves' secondary settlement differs with species: a comparison between cockle (Cerastoderma edule) and clam (Ruditapes philippinarum) juvenile resuspension. Mar. Biol. 128, 639-648.

Delgado, M., Pérez-Camacho, A., 2007. Comparative study of gonadal development of Ruditapes philippinarum (Adam and Reeve) and Ruditapes decussatus (L.) (Mollusca: Bivalvia): Influence of temperature. Sci. Mar. 71, 471-484.

Drummond, L., Mulcahy, M., Culloty, S., 2006. The reproductive biology of the Manila clam, Ruditapes philippinarum, from the North-West of Ireland. Aquac. Res. 254, 326-340.

Fiori, S.M., Morsan, M., 2004. Age and individual growth of Mesodesma mactroides (Bivalvia) in the southern most range of its distribution. ICES J. Mar. Sci. 61, 1253-1259.

Flassch, J.P., Leborgne, Y., 1992. Introduction in Europe, from 1972 to 1980, of the Japanese Manila clam (Tapes philippinarum) and the effects on aquaculture production and natural settlement. ICES Mar. Sci. Symp. 194, 92-96.

Gayanilo, F.C., Sparre, P., Pauly, D., 2005. FAO-ICLARM stock assessment tools II - Revised version. Computerized information series, vol. 8. FAO, Rome, p. 168.

Goulletquer, P., Lombas, I., Prou, J., 1987. Influence du temps d'immersion sur l'activité reproductrice et sur la croissance de la palourde japonaise Ruditapes philippinarum et l'huître japonaise Crassostrea gigas. Haliotis 16, 453-462.

Hiddink, J.G., Marijnissen, S.A.E., Troost, K., Wolff, W.J., 2002. Predation on 0-group and older year classes of the bivalve Macoma balthica: interaction of size selection and intertidal distribution of epibenthic predators. J. Exp. Mar. Biol. Ecol. 269, 223-248.

Holland, D.A., Chew, K.K., 1974. Reproductive cycle of the Manila clam (Venerupsis japonica) from Hood Canal, Washington. Proc. Natl. Shellfish. Ass. 64, 53-58.

Humphreys, J., Caldow, R.W.G., McGrorty, S., West, A.D., Jensen, A.C., 2007. Population dynamics of naturalised Manila clams Ruditapes philippinarum in British coastal waters. Mar. Biol. 151, 2255-2270.

Ishii, R., Sekiguchi, H., Nakahara, Y., Jinnai, Y., 2001. Larval recruitment of the Manila clam Ruditapes philippinarum in Ariake Sound, southern Japan. Fish. Sci. 67, 579-591.

Jensen, A.C., Humphreys, J., Caldow, R.W.G., Grisley, C., Dyrynda, P.E.J., 2004. Naturalization of the Manila clam (Ruditapes philippinarum), an allien species, and establishment of a clam fishery within Poole Harbour, Dorset. J. Mar. Biol. Assoc. U. K. 84, 1069-1073.

Kanazawa, T., Sato, S.I., 2007. Environmental and physiological controls on shell microgrowth pattern of Ruditapes philippinarum (Bivalvia: Veneridae) from Japan. J. Molluscan Stud. 74, 89-95.

Laruelle, F., 1999. Phenologie et déterminisme de la reproduction chez Ruditapes decussatus et Ruditapes philippinarum en Bretagne. Thesis. Université de Bretagne Occidentale. pp. 1-216.

Laruelle, F., Guillou, J., Paulet, Y.M., 1994. Reproductive pattern of the clams, Ruditapes decussatus and R. philippinarum on intertidal flats in Brittany. J. Mar. Biol. Assoc. U. K. 74, 351-366.
Lucas, A., 1965. Recherches sur la sexualité des mollusques bivalves. Thesis. Université de Rennes. pp. 1-135.

Maitre-Allain, T., 1985. Biologie de la reproduction de la palourde japonaise Ruditapes philippinarum dans l'étang de Thau (Hérault, France). Rapp. et Proc. Verb. Réun. Commiss. Int. Explor. Sci. Mer. Méditerr. Monaco 29, 109-110.

Mann, R., 1979. The effect of temperature on growth, physiology, and gametogenesis in the Manila clam Tapes philippinarum. J. Exp. Mar. Biol. Ecol. 38, 121-133.

Maronas, M.E., Darrigan, G.A., Sendra, E.D., Breckon, G., 2003. Shell growth of the golden mussel, Limnoperna fortunei (Dunker, 1857) (Mytilidae), in the Rio de la Plata, Argentina. Hydrobiologia 495, 41-45.

Masu, T., Watanabe, S., Aoki, S., Katayama, S., Fukuda, M., Hino, A., 2008. Establishement of shell growth analysis technique of juvenile Manila clam Ruditapes philippinarum: semidiurnal shell increment formation. Fish. Sci. 74, 41-47.

McArthur, V.E., 1998. Predation and survival of juvenile Cerastoderma glaucum Bruguière (Mollusca: Bivalvia) in a coastal lagoon. J. Exp. Mar. Biol. Ecol. 225, 79-97.

Meneghetti, F., Moschino, V., Da Ros, L., 2004. Gametogenic cycle and variations in oocyte size of Tapes philippinarum from the Lagoon of Venice. Aquaculture 240, 473-488.

Metaxatos, A., 2004. Population dynamics of the venerid bivalve Callista chione (L.) in a coastal area of the eastern Mediterranean. J. Sea Res. 52, 293-305.

Nakamura, Y., Hagino, M., Hiwatari, T., Iijima, A., Kohata, K., Furota, T., 2002. Growth of the Manila clam Ruditapes philippinarum in Sanbanse, the shallow coastal area in Tokyo Bay. Fish. Sci. 68, 1309-1316.

Nosho, T.Y., Chew, K.K., 1972. The setting and growth of the Manila clam, Venerupsis japonica (deshayes), in Hood Canal, Washington. Proc. Natl. Shellfish. Ass. 62, 50-58.

Ohba, S., 1959. Ecological studies in the natural population of a clam, Tapes japonica with special reference to seasonal variations in the size and structure of the population and to individual growth. Biol. J. Okayama Univ. 5, 13-42.

Pauly, D., 1983. Some simple methods for the assessment of fish stocks. FAO Fish. Tech. Pap. 234:52.

Pauly, D., Moreau, J., 1997. Méthodes pour l'évaluation des ressources halieutiques. In Cépaduès-Éditions, editor editors. Toulouse: Cépaduès-Éditions. pp. 1-288.

Pauly, D., Munro, J.L., 1984. Once more on the comparison of growth in fishes and invertebrates. Fishbyte 2, 21-22.

Peharda, M., Richardson, C.A., Mladineo, I., Sestanovic, S., Popovic, Z., Bolotin, J., Vrgoe, N., 2007. Age, growth and population structure of Modiolus barbatus from the Adriatic. Mar. Biol. 151, 629-638.

Ponurovsky, S.K., Yakovlev, Y.M., 1992. The reproductive biology of the Japanese littleneck, Tapes phillipinarum (A. Adams and Reeve, 1850) (Bivalvia: Veneridae). J. Shellfish Res. 11, 265-277.

Plus, M., Maurer, D., Stanisière, J.-Y., Dumas, F., 2006. Caractérisation des composants hydrodynamiques d'une lagune mésotidale, le bassin d'Arcachon. IFREMER report pp. 1-58.

Ponurovskii, S.K., Selin, N.I., 1988. Distribution, population structure, and growth of the bivalve mollusk Ruditapes philippinarum in Vostok Bay, Sea of Japan. Sov. J. Mar Biol. 1, 11-15.

Ramon, M., 2003. Population dynamics and secondary production of the cockle Cerastoderma edule (L.) in a backbarrier tidal flat of the Wadden Sea. Sci. Mar. 67, 429-443.

Robert, R., Trut, G., Laborde, J.-L., 1993. Growth, reproduction and gross biochemical composition of the Manila clam Ruditapes philippinarum in the Bay of Arcachon, France. Mar. Biol. 116, 291-299.

Robinson, A.M., Breese, W.P., 1984. Gonadal development and hatchery rearing techniques for the Manila clam, Tapes philippinarum (Adams \& Reeve). J. Shellfish Res. 4, 161-163.

Rodriguez-Moscoso, E., Pazo, J.P., Garcia, A., Fernandez-Cortes, F., 1992. Reproductive cycle of Manila clam, Ruditapes philippinarum (Adams \& Reeve 1850) in Ria of Vigo (NW Spain). Sci. Mar. 56, 61-67.

Sanchez-Salazar, M.E., Griffith, C.L., Seed, R., 1987. The effect of size and temperature on the predation of cockles Cerastoderma edule (L.) by the shore crab Carcinus maenas (L.). J. Exp. Mar. Biol. Ecol. 111, 181-193.

Thompson, R.J., 1984. Production, reproductive effort, reproductive value and reproductive cost in a population of the blue mussel Mytilus edulis from a subarctic environment. Mar. Ecol. Prog. Ser. 16, 249-257.

Toba, M., 2004. The decline of Manila clam stock in Tockyo Bay. Bull. Fish. Res. Agen. 1, 13-18.

Toba, M., Yamakawa, H., Kobayashi, Y., Sugiura, Y., Honma, K., Yamada, H., 2007 Observations on the maintenance mechanisms of metapopulations, with special reference to the early reproductive process of the Manila clam Ruditapes philippinarum (Adam \& Reeve) in Tokyo Bay. J. Shellfish Res. 26, 121-130.

Underwood, A.J., 1997. Experiments in Ecology - Their Logical Design and Interpretation Using Analysis of Variance. Cambridge University Press, pp. 1-504.

Walne, P.R., Mann, R., 1975. Growth and biogeochemical composition in Ostrea edulis and Crassostrea gigas. In: Barnes, H. (Ed.), 9th European Marine Biology Symposium. Aberdeen University Press, pp. 587-607.

Xie, Q., Burnell, G.M., 1994. A comparative study of the gametogenic cycles of the clams Tapes philippinarum (Adams \& Reeve 1850) and Tapes decussatus (Linnaeus) on the south coast of Ireland. J. Shellfish Res. 13, 467-472. 